\title{
TRIPLE BRANCHING OF RETINAL BLOOD VESSEL*
}

\author{
BY
}

\section{J. PRIMROSE \\ London}

THE incidence of triple branching of retinal blood vessels is of sufficient rarity to be noteworthy. Duke-Elder (1938) quoted only four authors, only one of whom had described more than one case, viz. Liebitsky (1928), who cited five occurrences. The anatomy books state categorically that retinal vessels divide dichotomously (Wolff, 1948; Salzmann, 1912), as also does Michaelson (1954), who has made a special study of developing retinal blood vessels. There are so few cases as to indicate this to be the exception which proves some rule. The following case is the only occurrence I have noticed, though I have seen a close approximation (not so uncommon) where two dichotomous branchings came sufficiently near to coinciding to suggest that triple branching might thereby arise, as was suggested by Liebitzky.

The patient, an elderly-looking man aged 62 years, attended on account of diplopia of recent onset. A slight right superior oblique palsy was found. The fundi were healthy apart from involutionary sclerosis and occasional colloid bodies. The right fundus showed a triple division of the superior temporal artery (Figure).

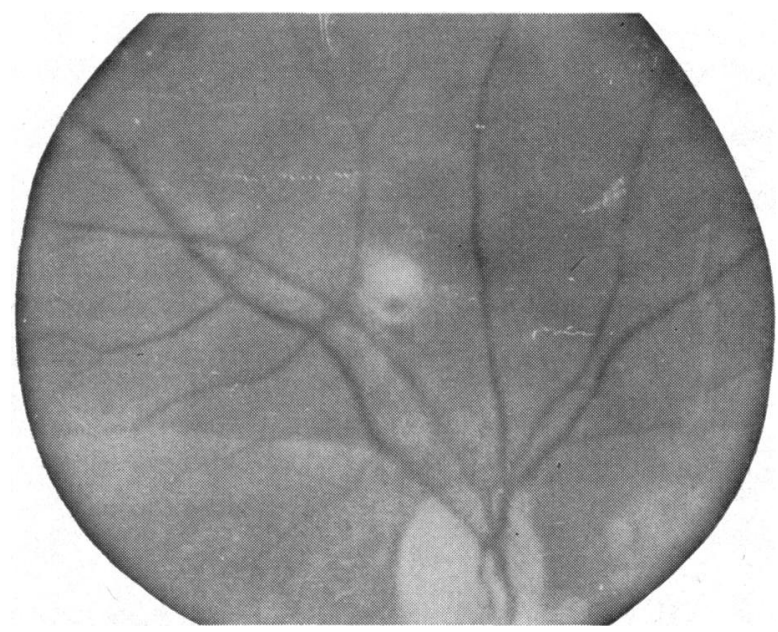

FIGURE.-Right fundus showing triple branching of superior temporal artery.

* Received for publication May 11, 1959. 


\section{Discussion}

Michaelson postulates a tissue factor for vessel growth and gives good reasons why an artery need never cross an artery, nor a vein cross a vein. The occurrence of such a crossing has been reported as an exception by Snodgrass (1956). Let us see if the same reasons may apply here. The need for an additional artery (or vein) may be the accumulation of metabolites in, or relatively anoxia of, the developing tissue outgrowing what blood supply already exists. As soon as this need is met by a branch vessel, then no further branch is required until beyond the zone of diffusion of metabolites, oxygen, etc. The increase of area of vessel wall inherent in any junction would increase that zone of diffusion and inhibit thereby any adjacent branch. The capillary-free zone surrounding the arterioles but not the veins (Michaelson, 1954), and the marked effect of oxygen on developing retinal vessels (Ashton, Ward, and Serpell, 1954) strongly suggest that oxygen requirement alone is sufficient stimulus without postulating special tissue factors.

These influences are at work on developing blood vessels. But there may be an inherent tendency of vessels to bud and throw out loops, and it may in fact be the reverse influence of full oxygenation and removal of metabolites which checks more widespread growth of blood vessels. As branches arise by budding, it may be that, all the effort for budding having been used up at one focus, the parent vessel will have grown further before any more effort is available for fresh budding. Or, in other words, it may be that the developing bud itself inhibits the growth of any other bud nearby.

It is significant that, in the cases illustrated in the literature as in that described above, the two side-branches are at right angles to the main stem and its continuation running as directly away from each other as possible; also the three branches are practically all the same size. This suggests twin buds arising simultaneously to account for the triple branching, rather than two dichotomous divisions so close together as to coincide.

\section{REFERENCES}

Ashton, N., WARD, B., and Serpell, G. (1954). Brit. J. Ophthal., 38, 397.

Duke-Elder, S. (1938). "Text-book of Ophthalmology", vol. 2, p. 1386. Kimpton, London. LIEBITZKY, H. (1928). Klin. Mbl. Augenheilk., 81, 42.

Michaelson, I. C. (1954). "Retinal Circulation in Man and Animals". p. 102, 130. Thomas, Springfield, Ill.

SalzmanN, M. (1912). "Anatomie und Histologie des menschlichen Augapfels", p. 195. Deuticke, Leipzig.

SNOdgrass, M. B. (1956). Brit. J. Ophthal., 40, 754.

WolfF, E. (1948). "Anatomy of the Eye and Orbit", 3rd ed., p. 109. Lewis, London. 